\title{
Conceptual Metaphor about Corona Virus: Cognitive Semantic Analysis
}

\author{
Irzam Sarif S', Yuyu Yohana Risagarniwa², Nani Sunarni ${ }^{3}$ \\ Faculty of Cultural Studies, Padjadjaran University 1,2,3 \\ Email: Irzamsarifs@yahoo.com¹
}

Submitted: 08/06/2020

Revised: 20/06/2020

Accepted: 03/11/2020

E-ISSN : $2579-4574$

P-ISSN : 2549-7359

\begin{abstract}
Conceptual metaphors are the result of mental construction, conceptualization of the experience of human life. In Japanese, metaphorical features are often found in conveying information so that information can be easily understood. This study aimed to describe the conceptual metaphors found at the Japanese Prime Minister's Press Conference, Shinzo Abe on March 14 and 28, 2020 through the official website kantei.go.jp. The research method used was descriptive qualitative analysis. Data were collected by taking text that contained metaphorical elements and then selected. Data selection was based on the basic principle of metaphor, which was the mapping from the source domain to the target domain. Then the data were classified based on the type of metaphor by Lakoff and Johnson and the type of image scheme by Cruse and Croft. Based on the study done, there were three types of conceptual metaphors, 1) Structural metaphors with conceptuals meaning of enemy, medical treatment, control, and mind; 2) Orientational metaphors with conceptual meaning of disadvantage, and approval; 3) Ontological metaphors with conceptuals meaning of finance, and emotion. In addition, there were also six types of image schemes, namely the image scheme of Strength, Existence, Identity, Scale, Space, and Unity.
\end{abstract}

Keywords: Conceptual Meaning, Press Conference, Cognitive Semantic, Image Scheme

\section{https://ojs.unm.ac.id/eralingua}

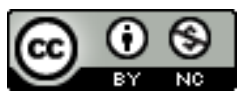

This work is licensed under a Creative Commons Attribution-NonCommercial 4.0 International License 


\section{INTRODUCTION}

Language has a dynamic nature that will continue to develop bringing new phenomena to its users. Widhiarso (2001) said that language has a very important role in the human thought process. The relationship between language and mind is seen on the assumption that language influences the way humans view the world and the minds of the individual users of that language. Further Sutedi (2014) said that language is one of the tools of human communication which plays an important role as a means of communication in human life when conveying ideas, thoughts, desires, and willing to someone both verbally and in writing, so that the meaning conveyed can be received clearly. In the process of delivering each concept with all of its cognition, language is used as a medium for the delivery of these concepts. In language study, it is called a cognitive linguistics. Cognitive linguistics according to (Evans \& Green, 2006) is a study to know how a person thinks of something spoken through his language. Therefore, each concept can be interpreted cognitively depending on one's experience.

This approach has been widely used by previous study such as Lyra (2018) with the title "Konseptualisasi Sosiokultural Masyarakat Sunda dalam Metafora Konseptual Bagian Tubuh" and Tawami (2018) with the title "Metafora Konseptual pada Wacana Retorika Politik". Cognitive semantics is an experience-based approach that one of the main focuses of the study is metaphor. Metaphor is part of the system of human thinking that conceptualizes one concept to another in the form of life behavior as a sociocultural and historical experience of a society. This is what is referred to as a conceptual metaphor that is in line with Lakoff \& Johnson (2003).

Conceptual metaphor was first introduced by Lakoff and Johnson (1980). According to them, the metaphor was accidentally created but merged in everyday language. Therefore, people will unwittingly bring up metaphors in their speech. The metaphor arises from the results of mental construction, conceptualization of human life experiences. This conceptual metaphor also becomes a criticism of the view that still considers that the metaphor was deliberately formed and created, so that the writings and works of copyright have a memorable and poetic impression.

This metaphor has also been used by previous researcher, Idrus (2015) with the title "Metafora Deskripsi Fisik Tokoh Wanita dalam Novel Noruwei No Mori Karya Haruki Murakami”. Metaphor by Lakoff \& Johnson (1980; 2003) are divided into three types, namely structural metaphor, orientational metaphor, and ontological metaphor. Structural metaphor is realized through the transfer of one concept to another. Orientational metaphors are metaphors that relate to human experience, for example to concrete an abstract become real. Ontological metaphor is metaphor that conceptualize thoughts, experiences, other things abstract to something that has physical properties.

According to Lakoff \& Johnson (1980; 2003), conceptual metaphor has three components, the first, the source domain. This component is concrete. The source domain consists of a group of entities, attributes, or processes that are connected literally, and semantically stored in the mind. These things are expressed through a set of words or expressions that considered to be grouped in similar groups which 
are often called linguists as lexical groups or lexical fields. In the classical view, this component is called as a vehicle.

The next is the target domain. The target domain tends to be more abstract and follows the structure of the source domain through mapping. This mapping is called conceptual metaphor. Therefore, entities, attributes, and processes in the target domain are believed to be related to each other as mapped patterns of the relationship of entities, attributes, and processes in the source domain. At the language level, all entities, attributes, and processes in the target domain are localized through words and expressions from the source domain. In the classical view, this component is called as a tenor. The last component is correspondence or mapping. This mapping produces a point of similarity (ground), it means to show the similarity between the target to the source. This cannot be reversed. In the classical view, this is called as a basic metaphor.

Image scheme is an important form of cognitive semantic conceptual structure. In addition, image scheme is structures of meaning derived from experience that results from how the body interacts with the world. The Image Scheme according to Cruse and Croft (2004) used in this study are (1) Space consists of Up-Down, Front-Back, Left-Right, Near-Far, Center-Periphery, and Contact. (2) Scale consists of Path. (3) Container consists of Containment, In-Out, Surface, Full-Empty, and Content. (4) Force consists of Balance, Counterforce, Compulsion, Restraint, Enablement, Blockage, Diversion, and Attraction. (5) Unity/Multiplicity consists of Merging, Collection, Splitting, Iteration, Part-Whole, Mass-Count, and Link. (6) Identity consists of Matching, and Superimposition. Last, (7) Existence consists of Removal, Bounded Space, Cycle, Object, and Process.

The previous study that relevant to this study is, first, by Haula (2018), with the title "Konseptualisasi Metafora dalam Rubrik Opini Kompas Tahun 2018: Kajian Semantik Kognitif". The discussion was oriented towards cognitive semantic studies with the aim of describing the types of metaphors and image schemes. The data source in this study was taken from the Kompas opinion rubric in 2018. The method used in this study was a qualitative descriptive method, while the theory referred to cognitive semantics, related to the types of metaphors by Lakoff and Johnson (1980) and theories about image schemes proposed by Cruse and Croft (2004).

The second study was by Saifudin (2018) with the title "Konseptualisasi Citra Hara 'Perut' dalam Idiom Bahasa Jepang". This study discussed the conceptualization of the Hara 'stomach' image for Japanese people. The data analyzed was 25 idioms that contain the word hara 'stomach' which was obtained from several Japanese idiom dictionaries. This study was based on cognitive linguistics, which connect with linguistic expression with human cognitive experience. The theory used in this study was the "conceptual metaphor theory" pioneered by Lakoff and Johnson (1980). This theory considers human perception, body parts, and world view of people as the basis for the structure of human language.

Based on some of the previous studies above, the similarity is all researchers used the conceptual metaphor theory by Lakoff and Johnson (1980). Because this metaphorical theory is the most updated theory in its application among other 
conceptual metaphorical theories. The difference is this study used data Covid-19 because this data is very relevant in accordance with the conditions that occur at this time and there are no researchers studying this.

Therefore, this study focused on conceptual metaphors that emphasized the types of metaphors, conceptual meanings, and image schemes in the delivery of information at the Press Conference about the Corona virus, by the Prime Minister of Japan, Shinzo Abe. This study chose his speech as the object because the Prime Minister is a representative of the current Japanese system of thinking, and also considered a trusted figure as well as a Japanese leader in providing information in the midst of the pandemic facing Japan.

\section{RESEARCH METHOD}

This study was a descriptive qualitative study. According to Creswell in his book Educational Research, qualitative is a type of research which the researcher is very dependent on information from the object/participant on: broad scope, general questions, data collection consisting mainly of words/texts from participants, explain and analyze words and conduct research subjectively (Creswell, 2008: 46). This study described data that contain metaphorical expressions. The type of data was written data. Data sources in this study were all data that contain metaphorical expressions obtained from the Press Conference of the Prime Minister of Japan, Shinzo Abe on March 14 and 28, 2020 through the official website kantei.go.jp. with preliminary data in Japanese language. The collected data was transliterated and translated into Indonesia language both in word meaning and the case meaning.

At the data collection stage, the method used was observational method, note-taking technique. Observational method is method of collecting data by observing the use of the language (Sudaryanto, 2015). In collecting the data, the objects observed were all text that contain metaphorical expressions. The selection of data was based on the basic principle of metaphor, which was the mapping from the source to the target domain. Data that conformed to the basic principles of metaphor are then noted in the corpus of data. Then, the note-taking technique was used to note all the data collected and then analyzed using the cognitive semantic analysis approach. Cognitive semantics according to Evans (2007) is an approach that study about meaning through one's cognitive system. In this approach, there were 3 things that focus of the discussion, namely first, identifying the types of metaphors used by Lakoff \& Johnson (1980; 2003). Second, examined the conceptual meaning using Lakoff \& Johnson (1980; 2003). Finally, reviewed the image scheme based on the image scheme approach by Cruse and Croft (2004).

\section{RESULTS AND DISCUSSION}

The results of this study were classified based on the type of metaphor found. It was found 10 data, then the metaphors were analyzed based on its conceptual meaning. The last was the determination of the image scheme. The followings are a presentation of the results of the structural, orientational and ontological metaphor analysis according to Lakoff \& Johnson (1980; 2003). 


\section{Structural Metaphor}

The followings are the data that containing expressions about structural metaphor.

(1) Data : 打ち勝つことができる。

$$
\begin{aligned}
& \text { /Uchikatsu koto ga dekiru/ } \\
& \text { Conquer } \\
& \text { 'We can Conquer it' }
\end{aligned}
$$

Analysis :

The metaphorical expression in the data above was shown by the linguistic marker conquer. The word conquer in the data (1) above according to the Japanese Dictionary online has a lexical meaning to subdue, defeat the enemy. For example: 彼 らは敵に打ち勝った/karerawa tekini uchikatta/ 'They conquered their opponent'. The source domain in this data was conquer and the target domain was the corona virus. The relationships between the source and target domain were have a target and detrimental. Then, the conceptual meaning obtained was the enemy. In this case, the corona virus which considered to be an enemy is rapidly spreading among humans. Thus, this corona virus must be conquered to stop its spread. So, this data had an image scheme of Force sub-scheme Counterforce. The type of metaphor in this data was structural metaphor. Because the concept/character of conquer possessed by the enemy is transferred to the corona virus which must be conquered/defeated.

Image : Force sub-scheme Counterforce

Scheme

(2) Data

$$
\begin{aligned}
& \text { :..見えないウイルスと闘うという前例のない、... } \\
& \text { /mienai uirusu to tatakau to iu zenrei no nai/ } \\
& \text { invisible virus with fight } \quad \text { before not } \\
& \text { '...Unprecedented fight against invisible viruses...' (March } 14^{\text {th }} \\
& \text { 2020) }
\end{aligned}
$$

Analysis :

The word fight in data (2) above according to the online Japanese Dictionary has lexical meaning battle, conflict, struggle, competition. For example: 兵士たちは 戦いの準備ができている/heishitachiwa tatakaino junbiga dekiteiru/ 'The army is ready to fight'. The source domain in this data was fight and the target domain was corona virus. The relationships between the source and target domain were have a target and detrimental (for the loser). Then, the conceptual meaning obtained was the enemy. In this case, the virus was considered an enemy and its target is the human body. Humans fight against virus to keep their immune system. So, this data had an image scheme of Force sub-scheme Counterforce. The type of metaphor in this data was structural metaphor. Because the concept/character of fight possessed by army in order to against the enemy whose enemy characteristics were transferred to the virus that must be conquered/defeated.

Image :Force sub-scheme Counterforce

Scheme 
(3) Data

\begin{tabular}{|c|c|}
\hline $\begin{array}{l}\text { /Jinrui wa kore made ikudo mo kansen-shō } \\
\text { sarasarenagara/ }\end{array}$ & no kyōi ni \\
\hline $\begin{array}{l}\text { human until now several times infectious diseases } \\
\text { 'Humans have been threatened several times } \\
\text { diseases,...' (March 14 }{ }^{\text {th }} \text { 2020) }\end{array}$ & $\begin{array}{l}\text { threatened } \\
\text { by infectious }\end{array}$ \\
\hline
\end{tabular}

Analysis :

The word threatened in data (3) above according to the online Japanese dictionary has a lexical meaning in danger, stating the intention to do something detrimental. For example: 私たちは命の倠威にさらされていた/watashitachiwa inochino kyōi nisarasareteita/ 'We were under threat of life'. The source domain in this data was threaten and the target domain was infectious disease. The relationships between the source and target domain were have a target and detrimental (for the loser). Then, the conceptual meaning obtained was the enemy. In this case, the virus was considered an enemy that spread very rapidly, so this virus posed a threat to humans. This data has an image scheme of Force sub-scheme Counterforce. The type of metaphor in this data was structural metaphor. Because concept/character threaten possessed by enemy that transferred to the disease that considered a threat to haunt human life.

\section{Image :Force sub-scheme Counterforce \\ Scheme}

（4）Data ：...いわゆる医療崩壊を避けることができます。 /iwayuru iryō hōkai o yokeru koto ga dekimasu/ mentioned medical collapse avoid can '...can avoid what we called as medical collapse.' (March $28^{\text {th }} 2020$ )

\section{Analysis :}

The metaphorical expressions in the above data are indicated by linguistic markers medical collapse. The source domain was the medical collapse and the target domain was a shortage of tools and health workers. The relationship between the source and target domain in data (4) above was a condition. Then, the conceptual meaning obtained was the condition of medical treatment. In this case, the medical condition which was completely lacking would gradually collapse. This deficient condition was considered to be a medical cause to collapse. This data had an image scheme of Existence sub-scheme Process. The type of metaphor in this data was structural metaphor. Because the concept of medical collapse was transferred to a shortage of tools and health workers.

Image : Existence sub-scheme Process

Scheme

（5）Data : 日本としてリーダーシップを発揮してまいります。 /Nihon to shite rīdāshippu o hakki shite mairimasu/ Japan leadership to show will 'Japan will show its leadership.' $\quad$ (March $14^{\text {th }} 2020$ ) 
Analysis :

The metaphorical expression in the data above was indicated by linguistic marker leadership. The source domain was leadership and the target domain was power. The relationship between the source domain and the target domain was ability. Then the conceptual meaning obtained was Control. In this case, the word leadership did not only mean how to lead, but also showed a power as a big country. This data had an image scheme of Force sub-scheme Restraint. The type of metaphor in this data was structural metaphor. Because the concept of leadership was transferred to power which both could be able to regulate and control.

Image : Force sub-scheme Restraint

Scheme

(6) Data

: 地域の声、現場の声に耳を傾けることで、全国津々浦々、 ... /chiiki no koe, genba no koe ni mimi wo katamukeru koto de/ area voice, workplace voice listen to 'By listening to the voice of the area and the voice of the workplace

Analysis : ... (March 14 $\left.4^{\text {th }} 2020\right)$

The metaphorical expression in the data above was indicated by linguistic marker voice. The word in the data (6) above according to the online Japanese Dictionary has a lexical meaning of sounds issued from human mouth. The source domain was voice and the target domain was opinion. The concept transferred from the source to the target domain was talking or speaking. Then, the conceptual meaning obtained was mind. In this case, a voice was a way to argue the concept of mind delivered. This data had an image scheme of Scale sub-scheme Path. Therefore, the metaphorical feature in this data was used to transfer the voice concept of the source domain as an identity to an opinion as the target domain (structural metaphor).

Image : Scale sub-scheme Path

Scheme

Based on the findings of some structural metaphor data above, when compared with the results of previous studies as explained in the introduction, it was found that this structural metaphor has a conceptual metaphorical similarity that more directed to how to transfer/move the characteristics of a concept to other concept in showing the purpose of the metaphorical expression, certainly depended on the object under study. The difference is the image scheme found, which in this finding emphasized the Force, Existence, and Scale scheme in the process of the image scheme of the metaphor.

\section{Orientational Metaphor}

The followings are the data that containing expressions about orientational metaphor.

（7）Data：今後、世界経済の更なる落ち込みも懸念されます。 /kongo, sekai keizai no saranaru ochikomi mo kenensaremasu/ 
from now on, economy global will fall concern.

'There is concern that the global economy will fall further in the future.' (March 14 ${ }^{\text {th }}$ 2020)

Analysis :

The metaphorical expression in the data above was indicated by linguistic markers falling. The source domain was fall and the target domain was Economy. The relationship of the concept that transferred from the source domain to the target domain was a condition. Then, the conceptual meaning obtained was a condition of disadvantage. The word fall has the meaning of going down. The concept of the word fall described the condition as an entity. The entity of a fall is a not good condition, down in value. So, the word fall on the data illustrated image scheme of Space sub-scheme Up-Down between the source and target domains based on adverse circumstances. Up orientation means in line with positive things and Down orientation in line with negative things. So that the metaphorical feature in this data is used to concretize the concept of disadvantage (the experience of human life) into more real fall which is classified as an orientational metaphor.

Image :Space sub-scheme Up-Down

Scheme

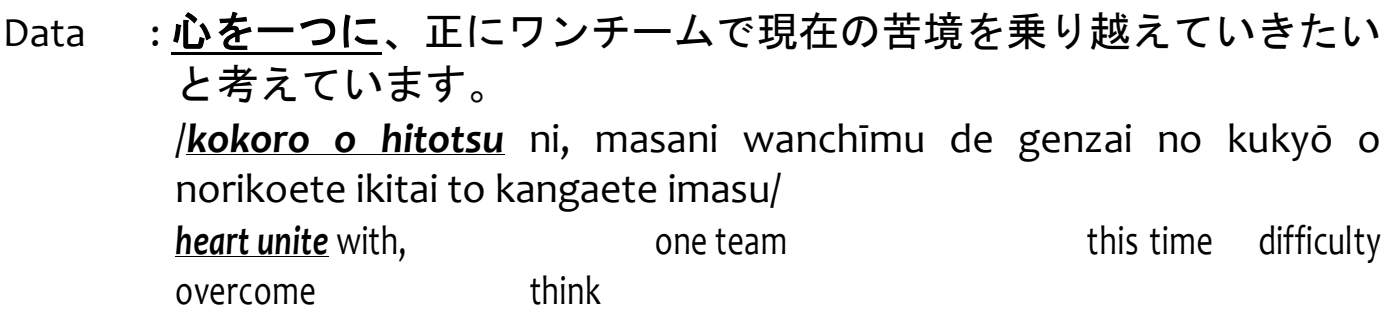

Analysis :

'By uniting our hearts, we want to overcome this problem with one team.' (March 14 ${ }^{\text {th }}$ 2020)

The metaphorical expression in the above data was indicated by linguistic marker uniting. The source domain was uniting, and the target domain was the heart. This phrase consists of two words namely united has lexical meaning of combining into one and heart has lexical meaning of organs of the body. The concept transferred from the source domain to the target domain was combines things together. Then, the conceptual meaning obtained was approval. In this case, the heart was considered as a place for all feelings and a place to store different meanings between one individual and another (difference). So, to unite the heart is to combine different things into one (same direction). This data had an image scheme of Unity/Multiplicity sub-scheme Merging. So that the metaphorical feature in this data was used to concretize the concept of approval to be more real based on the experience of human life unite the heart which was classified as an orientation metaphor

Image : Unity/Multiplicity sub-scheme Merging

Scheme

Based on the findings of the orientational metaphor above, when compared with the results of previous studies as explained in the introduction, it was found 
that this orientational metaphor had a conceptual metaphorical similarity that more directed to human experience in showing the intentions of the metaphorical expression, certainly depended on the object study. The difference is that the image scheme found, which in this finding emphasized the Space, and unity/multiplicity scheme in the process of the image scheme of the metaphor.

\section{Ontological Metaphor}

The followings are the data that containing expressions about ontological metaphor.

(9) Data

: 感染が世界的な広がりを見せる中、日本を含む世界中のマーケッ トが動摇しており、...

/Kansen ga sekai-tekina hirogari o miseru naka, Nihon o fukumu sekaijū no mäkettoga douyoushite ori/

infection world spread Japan include around the world market will shake

'As the infection spreads worldwide, the market around the world,

Analysis : including Japan, will be shaken, ...' (March 14 $4^{\text {th }}$ 2020)

The metaphorical expression in the above data was indicated by linguistic marker market. This word in the data (8) above according to the Japanese Dictionary online has a lexical meaning of the place of sale and purchase (concrete noun). The source domain was the market and the target domain was the economy. The relationship of the concept between the source and target domain was $a$ condition. Then, the conceptual meaning obtained was the condition of finance. In this case, the market was a place for buying and selling as an illustration of an economy in managing finances. This data had an image scheme of Identity subscheme Matching. But this noun in the context of this data referred to world economic condition in the form of abstract object (matching). Therefore, the metaphorical feature in this data was used to concretize the concept of abstract economics (non-physical) to the concrete concept of the market (physical) (ontological metaphor).

Image : Identity sub-scheme Matching

Scheme

（10） Data : 皆さんの活気あふれる笑顔を取り戻すため、... /minasan no kakki afureru egao wo torimodosu tame/ everyone lively smile mengembalikan untuk

'To regain everyone lively smile, ...' (March 28 ${ }^{\text {th }}$ 2020)

Analysis :

The metaphorical expression in the above data was indicated by linguistic marker Smile. The data source domain above was smile and the target domain was happiness. The relationship of the concept that transferred from the source to the target domain was a feeling. Then, the conceptual meaning obtained was emotion. Happiness is making physical conditions fun. The concept of happy and its opponent is sad mapped in the Up-Down dimension. So, this data had an image scheme of Space sub-scheme Up-Down. In the context of the data, happiness was considered 
as an object that must be recovered. The concept of happiness is not a concrete thing, but an abstract concept, and it could be identified through the look on one's smile. So, the happiness was concretized with a smile. the metaphorical feature in this data was used to concretize the abstract concept happiness to the concrete concept a smile (ontological metaphor).

Image :Space sub-scheme Up-Down

Scheme

Based on the findings of the ontological metaphor above, when compared with the results of previous studies as explained in the introduction, it was found that this orientational metaphor had a conceptual metaphorical similarity that more towards conceptualizing abstract things into concrete things in showing the purpose of the expression of the metaphor, certainly depended on the object under study. The difference is that the image scheme found, which in this finding emphasized the Space, and Identity scheme in the process of the image scheme of the metaphor.

\section{CONCLUSION}

The results of this study indicated that the metaphors found were divided into three types, they were 1) Six structural metaphor with conceptual meaning of enemy, medical treatment, control, and mind; 2) Two orientational metaphors with conceptual meaning of disadvantage, and approval; 3) Two ontological metaphors with conceptuals meaning of finance, and emotion. In addition, there were also six types of image schemes, namely the image scheme of Strength, Existence, Identity, Scale, Space, and Unity. The use of structural metaphor was more widely used in the Press Conference on the online site kantei.go.jp. Because the Japanese Prime Minister preferred to show a concept by using another concept to facilitate understanding of what he conveyed. This concept was simply transferred by simile. In this case, the Prime Minister of Japan wanted to convey the dangers of corona virus through the use of metaphorical features, especially structural metaphor that close to the daily life of Japanese society so that the information conveyed could be captured more easily.

\section{REFERENCES}

Creswell, J. W. (2008). Educational research: Planning, conducting, and evaluating quantitative and qualitative research. Upper Saddle River, NJ: Pearson/Merrill Education.

Cruse, D. A. dan Croft, W. (2004). Cognitive Linguistics. Cambridge: Cambridge University Press.

Evans, G. (2006). Cognitive Linguistics an Introduction. Edinburgh University Press.

Evans, V. (2007). A Glossary of Cognitive Linguistics. Edinburgh University Press. https://doi.org/10.1075/arcl.6.15cue

Haula, B., \& Nur, T. (2018). Konseptualisasi Metafora dalam Rubrik Opini Kompas Tahun 2018: Kajian Semantik Kognitif (The Conceptualization of Metaphor in The Rubric of Opinion Kompas 2018: A Cognitive Semantic). Mozaik Humaniora, 1(2), 149-156. 
Idrus. (2015). Metafora Deskripsi Fisik Tokoh Wanita dalam Novel Noruwei No Mori Karya Haruki Murakami. Jurnal Puitika, 11(1), 74-81.

Japan.kantei.go.jp/jp/98_abe/statement/2020/0314kaiken.html

Lakoff, G. and Jhonson, M. (1980). Methaphors We Live By. Chicago: The University of Chicago Press.

Lakoff, G. and Jhonson, M. (2003). Methaphors We Live By. Chicago: The University of Chicago Press.

Lyra, H. M., Wahya, \& Permadi, R. Y. (2018). Konseptualisasi Sosiokultural Masyarakat Sunda dalam Metafora Konseptual Bagian Tubuh. Metahumaniora, 8(1), 58. https://doi.org/10.24198/mh.v8i1.18874

Saifudin, A. (2018). Konseptualisasi Citra Hara 'Perut' dalam Idiom Bahasa Jepang. Japanese Research on Linguistics, Literature, and Culture, 1(1), 65-78. https://doi.org/10.33633/jr.v111.2130

Sudaryanto. (2015). Metode dan Aneka Teknik Analisis Bahasa Pengantar Penelitian Wahana Kebudayaan secara Linguistis. Yogyakarta: Sanata Dharma University Press.

Sutedi, D. (2014). Dasar-dasar Linguistik Jepang. Bandung: Humaniora

Tawami, T., \& Sari, R. P. (2018). Metafora konseptual pada wacana retorika politik. Jurnal AKRAB JUARA, 3(4), 59-69.

Widhiarso, W. (2001). Pengaruh Bahasa Terhadap Pikiran: Kajian Hipotesis Banyamin Whorf dan Edward Sapir. Yogyakarta: Fakultas Psikologi Universitas Gadjah Mada. 